Section Editor

Robert C. Griggs, MD
Editors' Note: In this week's WriteClick, Koehler and Erftemeijer and author Sohrab continue a lively debate over the artist Frans Hals' intent in employing a wavy borderline around certain figures in some of his later paintings. Sharma and Khandelwal comment on authors Shamy and Jaigobin's finding that $79 \%$ of surveyed neurologists would not attempt thrombolysis in patients with dementia.

—Megan Alcauskas, MD, and Robert C. Griggs, $M D$

\section{THE COMPLEXITIES OF ACUTE STROKE DECISION-MAKING: A SURVEY OF NEUROLOGISTS}

Mohit Sharma, Priyank Khandelwal, New York: Drs. Shamy and Jaigobin ${ }^{1}$ found that $79 \%$ of surveyed neurologists would not thrombolyze patients with dementia. We are surprised by this finding. Preexisting dementia is not a contraindication to the use of tissue plasminogen activator $(\mathrm{tPA}) .^{2}$ Even with strong evidence, clinical practice is heavily influenced by personal experiences and beliefs. Neurologists who have been practicing for more than 10 years are more likely to thrombolyze patients with dementia, which provides insight about the thought process among young neurologists.

The authors did not inquire whether patients' race, ethnicity, and educational status influenced the decision, because minorities are less likely to receive thrombolysis. ${ }^{3}$ This variation could be even more pronounced in developing/underdeveloped countries, where patients pay for thrombolysis themselves. Also, it would be interesting to know whether first responders — other than neurologists — who run a stroke code in community-based hospitals have different views regarding tPA administration.

Drs. Shamy and Jaigobin highlighted one of the many ethical and legal issues concerning the use of tPA that could eventually be detrimental to the patient's prognosis.

Author Response: Michel C.F. Shamy, Ottawa: We thank Drs. Sharma and Khandelwal for their comments. As they suggested, we suspect that experiences, beliefs, and biases present in developing countries are similar to those influences in developed countries. Moreover, resource limitations may amplify biases and health disparities. We agree that additional factors such as race/ethnicity, socioeconomic status, educational status, do-not-resuscitate status, and the ability to pay may also influence decision-making.

Regarding tPA use in patients with dementia, we suspect that this may be more complex. Patients with a good chance of improvement should not be deprived of tPA without good reason. While patients with dementia deserve to be treated with the best medical care, this care may not always mean heightened intervention. Dementia may be considered a terminal (i.e., palliative) diagnosis, and it may not always be ethically or economically appropriate to provide patients with aggressive and costly interventions like IV tPA. Physicians are allowed-and should have-opinions on issues like these, and they should be openly discussed.

(C) 2014 American Academy of Neurology

1. Shamy JC, Jaigobin CS. The complexities of acute stroke decision-making: a survey of neurologists. Neurology 2013; 81:1130-1133.

2. Alshekhlee A, Li CC, Cruz-Flores S, et al. Does dementia increase risk of thrombolysis? A case-control study. Neurology 2011;76:1575-1580.

3. Cruz-Flores S, Rabinstein A, Biller J, et al. Racial-ethnic disparities in stroke care: the American experience: a statement for healthcare professionals from the American Heart Association/American Stroke Association. Stroke 2011;42: 2091-2116.

\section{BLURRY AS TREMOR}

Peter J. Koehler, Heerlen; Antoon Erftemeijer, Haarlem, the Netherlands: Although Dr. Sohrab's suggestion is interesting, we present a more likely explanation of the blurry garment worn by one of the "Regentesses of the Old Men's Almshouse" (1664) by Frans Hals. One of us (A.E.) is curator at the Frans Hals Museum, Haarlem, the Netherlands, and studied the original painting more precisely. The woman (third from the left) is wearing a different white garment than the other Regentesses. Frans Hals tried to reproduce the semi-transparency of the garment; the "tremulous" edge was necessary to reproduce the transparency and the borders needed to be vague. This technique was also applied in "Portrait of 


\title{
Neurology
}

\author{
The complexities of acute stroke decision-making: A survey of neurologists \\ Mohit Sharma, Michel C.F. Shamy and Priyank Khandelwal \\ Neurology 2014;82;904 \\ DOI 10.1212/WNL.0000000000000199
}

This information is current as of March 10, 2014

Updated Information \& Services

References

Permissions \& Licensing

Reprints including high resolution figures, can be found at: http://n.neurology.org/content/82/10/904.1.full

This article cites 3 articles, 3 of which you can access for free at: http://n.neurology.org/content/82/10/904.1.full\#ref-list-1

Information about reproducing this article in parts (figures,tables) or in its entirety can be found online at:

http://www.neurology.org/about/about_the_journal\#permissions

Information about ordering reprints can be found online: http://n.neurology.org/subscribers/advertise

Neurology ${ }^{\circledR}$ is the official journal of the American Academy of Neurology. Published continuously since 1951, it is now a weekly with 48 issues per year. Copyright (C 2014 American Academy of Neurology. All rights reserved. Print ISSN: 0028-3878. Online ISSN: 1526-632X.

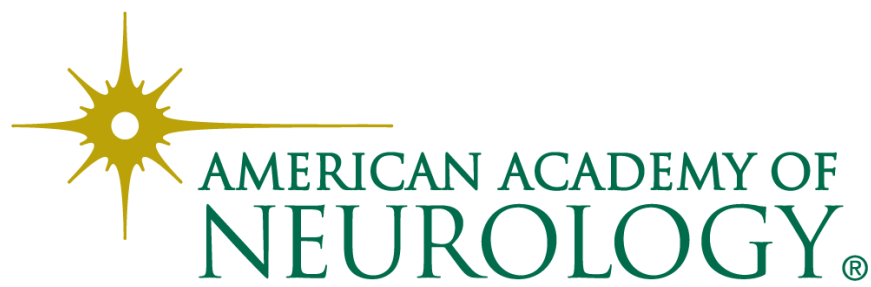

